\title{
The Epipalaeolithic-Neolithic as the pivotal transformation of human history
}

\author{
Trevor Watkins \\ School of History, Classics and Archaeology, University of Edinburgh, Edinburgh, UK \\ t.watkins@ed.ac.uk
}

\begin{abstract}
The objective of this paper is to set the Epipalaeolithic-Neolithic transformation (ENT) within the truly long-term of human evolutionary history. The Epipalaeolithic-Neolithic transformation takes us out of the world of Palaeolithic mobile foraging into a new world, in which the scale and organisation of the social group and the tempo of socio-cultural evolution were transformed. The scale and diversity of cultural innovation and social organisation can be seen to be linked in co-evolutionary feedback loops that have been characterised as 'cumulative culture', 'ratcheting' effects, or 'runaway' cultural evolution. The up-scaling of communities and the intensification of their interaction and networking enabled the emergence of super-communities that became the first large-scale societies, an inflection point on an accelerating curve of complex cultural, social and economic development, en route to emergent socio-political hierarchies, urbanism, kingdoms and empires.
\end{abstract}

KEY WORDS - Epipalaeolithic; Neolithic; Southwest Asia; cultural evolution; cumulative culture; cultural niche construction

\section{Prehod med epipaleolitikom in neolitikom kot ključna preobrazba v zgodovini}

\begin{abstract}
IZVLEČEK - Namen članka je umestitev preobrazbe v času med epipaleolitikom in neolitikom znotraj dejansko dolgoročne zgodovine človekove evolucije. Ta preobrazba je pomenila spremembo iz paleolitskih lovcev in nabiralcev $v$ nov svet, $v$ katerem sta se spremenila tako obseg kot organizacija družbene skupine kot hitrost družbeno-kulturne evolucije. Obseg in raznovrstnost kulturne inovacije in družbene organizacije je lahko povezana s co-evolucijskimi povratnimi zankami, ki so označene kot 'kumulativna kultura', učinek 'zobnikov' ali kulturna evolucija 'pobega'. Povečanje skupnosti in njihovih interakcij in mreženj je omogočilo pojav super-skupnosti, ki so postale prve družbe velikega obsega oz. točka preloma na krivulji hitrosti kompleksnega kulturnega, družbenega in ekonomskega razvoja, na poti $k$ nastajajočim hierarhijam, urbanizmu, kraljevinam in cesarstvom.
\end{abstract}

KLJUČNE BESEDE - epipaleolitik; neolitik; jugozahodna Azija; kulturna evolucija; kumulativna kultura; konstrukcija kulturne niše

\section{Introduction}

It has been the conventional wisdom that the first development of farming economies was the most important moment in history, serving as the foundation on which civilisations have been formed and on which the formation of our modern world is ultimately dependent. It is beyond question within the international community of Near Eastern Epipalaeo- lithic and Neolithic specialists that our 'Neolithic revolution' constitutes the most important research field in prehistoric archaeology. However, the Epipalaeolithic-Neolithic transformation (hereafter the ENT) is in an awkward situation. It is not at the transition between prehistory and history: for people concerned with historical periods, the Neolithic is 
remote prehistory, the province of archaeologists, potsherds, flints and animal bones, while for those concerned with the long-term questions of human evolution or Palaeolithic archaeology, the Neolithic is a brief postscript, the equivalent of 'the end of history'.

Many non-archaeologists think of the ENT as the pivot of human history in some way. To take just one example, the economic and social historian Paul Seabright (2004) has explored how our vast contemporary societies can function when we each live in The Company of Strangers. On the first page he writes: "Our teeming, industrialised, networked existence is not some gradual and inevitable outcome of human development over millions of years. Instead we owe it to an extraordinary experiment launched a mere ten thousand years ago. No-one could have predicted this experiment from observing the course of our previous evolution, but it would forever change the character of life on our planet." The 'extraordinary experiment' is the Neolithic of Southwest Asia. He contrasts the time before the Neolithic with the time since, amazed at how the sedentary farming populations of the Neolithic "with barely a pause for breath in evolutionary time ... had formed social organizations of startling complexity. Not just village settlements but cities, armies, empires, corporations, nation states, political movements, humanitarian organizations, even internet communities".

Paul Seabright is exceptional in that he has appreciated that there was much more to that period than simply the formulation of effective farming practices. For many non-archaeologist authors of general accounts of long-term human history, the domestication of plants and animals and the beginnings of farming are the significant advance of the Neolithic of Southwest Asia. If we find that non-archaeologists mistreat or misunderstand our Neolithic, it can only be because archaeologists have not been sufficiently clear and have failed to communicate their work and their ideas to the wider world, both among academics or other disciplines and the interested public. There are at least two ways to ensure that communication to a wider public is more effective: (a) we should set aside the kind of fact- and jargon-filled style that we use when writing for each other, and (b) adopt a framework for our narrative that is widely used beyond archaeo-logical circles. In this essay I want to try to set the ENT of Southwest Asia in a wider, evolutionary context, one that is based in the archaeology of the period, but is framed in terms that will be familiar because it has been developed and adopted by scientists from other disciplines.

While most research effort has been devoted to the identification of the when and where of domestication of plants and animals and the adoption of farming, and many in the wider public have learned that the transition from hunter-gatherer to farmer is the central issue in the Neolithic, I want to broaden the focus beyond the origins of agriculture. The progressive changes that led from classic Upper Palaeolithic hunting and gathering subsistence strategies to the effective farming strategies of the later aceramic Neolithic were obviously important and unprecedented, but they are one element in a larger, more complex process. My starting point in this paper is the observation that the general characteristic of the ENT is the accelerating pace of events that can be calibrated in the classification of the archaeological record. Through the approximately fifteen millennia of the Epipalaeolithic and Neolithic of Southwest Asia, the pace of cultural innovation and accumulation increased dramatically. At its simplest, using the characteristics of cultural assemblages to distinguish archaeological periods and sub-periods, Palaeolithic specialists work in terms of hundreds of thousands of years for the earliest periods, and tens of thousands of years in the more recent Palaeolithic. The pace quickens in the Epipalaeolithic of Southwest Asia, the Levant in particular: the early, middle and late sub-periods of the Epipalaeolithic each account for two or three millennia. Differentiating subphases within the late Epipalaeolithic Natufian, specialists begin to count in terms of one or two thousand years for an early, late, and final sub-phase. The sub-periods of the early Neolithic are counted in centuries, and the scale of archaeological periods continues to quicken in the following periods.

For that reason, I have become interested in graphs that depict accelerating change in human history or human evolution. Such upward curving graphs come at very different scales. A classic example that caught my eye some time ago, and which I at first misread, related to the Industrial Revolution in England (Clark 2007). In the late $18^{\text {th }}$ century, an almost flat line at the bottom of the graph began to curve upward, and, through the decades of the early $19^{\text {th }}$ century, it rapidly approached a cliff-like, near vertical acceleration. I was interested in the accelerating population density of the ENT, and this, I thought, could be a graph of the population explosion that accompanied the Industrial Revolution; in fact, it graphed over a few decades the growth of British 
household income. Industrialised production, a revolution in transport infrastructure, a rapid growth of population, the growth of household income, and the expansion of markets for all sorts of new products, and the ideas of Enlightenment thinkers (Mokyr 2009) were just some of the interacting elements in the Industrial Revolution that interacted upon one another in a complex of positive feedback loops.

\section{Acceleration and accumulation}

There have been accelerating curves of other kinds and on quite different scales earlier in human evolutionary history. Robin Dunbar, for example, has graphed the accelerating growth of the hominin brain and its pre-frontal cortex relative to the scale of the hominin body (Fig. 1). Dunbar was able to relate the neo-cortex ratio of the brain to social group among living primates (Dunbar 1997; 1998), and from that, to extrapolate the increasing scale of social groups across the three million or so years of human evolution. This is the basis of his 'social brain hypothesis', relating brain size and cognitive sophistication to the size of hominin social groups, arguing that these have co-evolved. Dunbar has also argued that gossip and chatting in small groups (that is, language) must have evolved to take over the role of one-to-one grooming. Although I do not think that Dunbar defines it as such, what he has been describing is a series of complex, cumulative, gene-culture co-evolutionary feedback loops that involve extend-

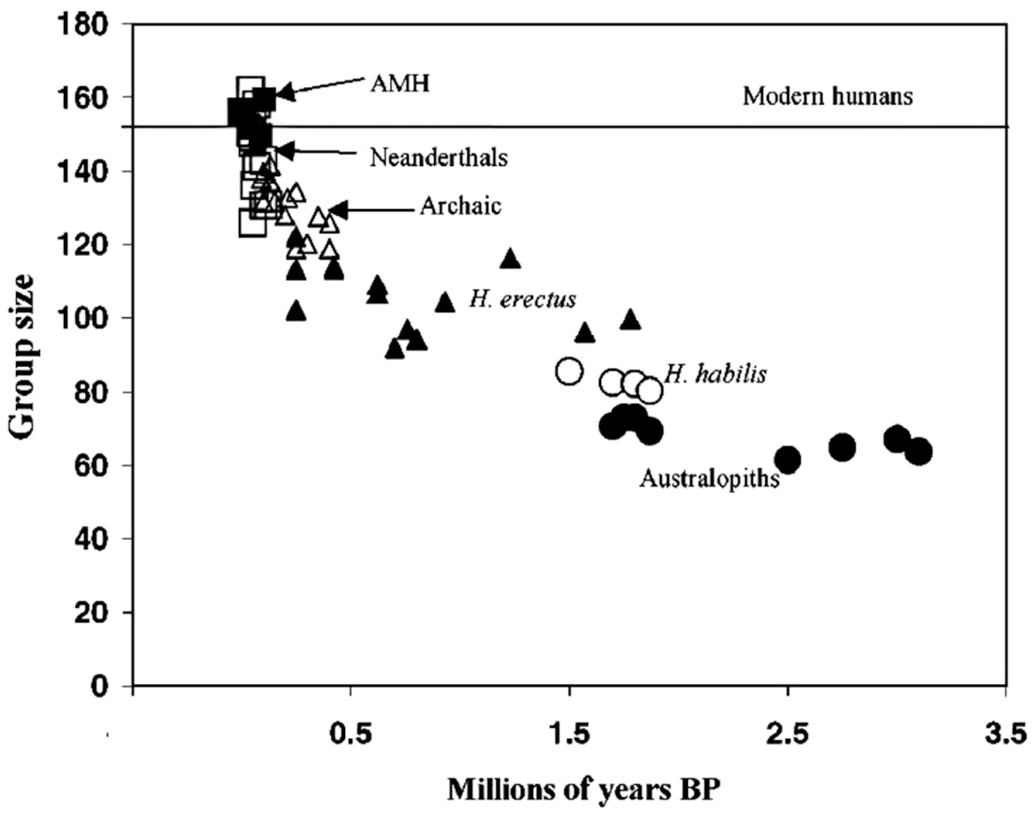

Fig. 1. Dunbar's representation of the increasing scale of the neo-cortex of the hominin brain. The timescale is in millions of years (and runs from right to left). The graph shows how increasing neo-cortex ratios relate to increasing social group size. ed human infancy, the plasticity of the human brain, the expansion of its cognitive capacities, the increase in human social group size, and language as the mode of communication and socialisation that kept groups together and cohesive. Just as Clark's graphing of the explosive growth of family income represents one element in the complex of the industrial revolution, so Dunbar's graphing of the accelerating expansion of the hominin neo-cortex ratio also represents one element in a complex of evolutionary interactions.

Dietrich Stout and a French colleague, Thierry Chaminade, have taken a somewhat different route through the evolutionary complex. They argue for the coevolution of cognitive skills, language and the ability to accumulate a sophisticated cultural package of stone tool-making skills (Stout, Chaminade 2009; 2012). Again, their graph (Fig. 2) shows an accelerating curve through the long term of the Pleistocene, but what is graphed here is the increasing flexibility of tool-making technology. This research adds practical and conceptual cultural knowledge to the equation of co-evolution of cognition, scale of social group, language and culture.

In his book The Evolved Apprentice Kim Sterelny, a philosopher interested in (human) evolutionary theory, traces the long-term development of cooperation, and the evolution of social and cognitive skills embedded in a cultural niche adapted for cultural transmission (Sterelny 2011). Sterelny is a leading figure among those who have been developing the idea that the human cultural niche evolved to support increasingly large-scale cooperation and increasingly effective social learning. Certainly, by the time of Homo sapiens, young people had become very adept at working out who were the best teachers from whom to learn advanced cultural skills, and there were cultural norms that enabled skilled and experienced older people to transmit their skills - what Sterelny calls apprentice learning. Considering how sophisticated and complex Homo sapiens cultures were by the Upper Palaeolithic, Sterelny at that time found it difficult to think how to account for the sudden and dramatic changes 


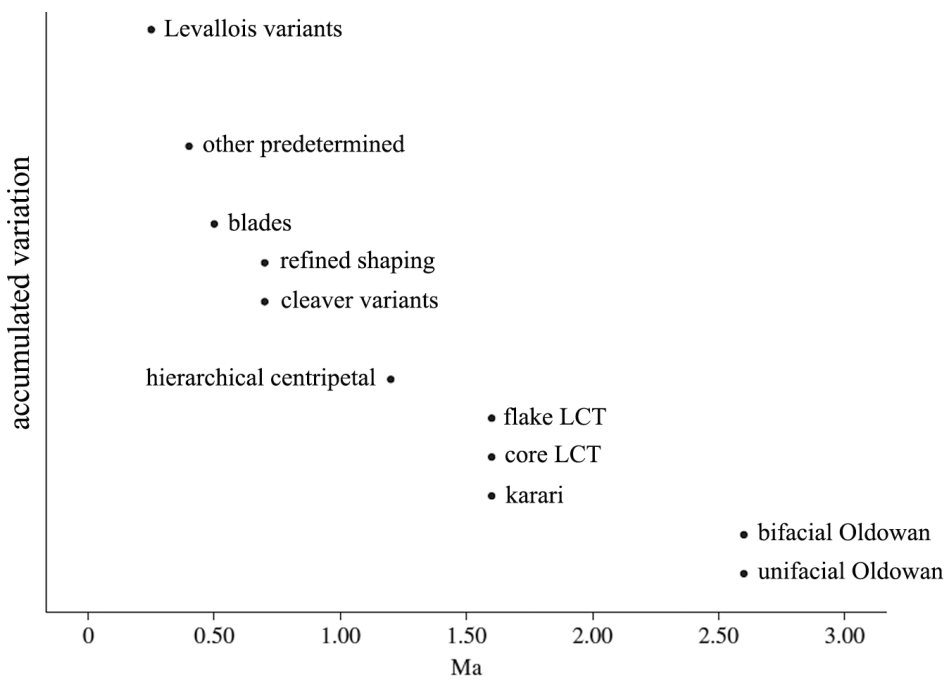

Fig. 2. Stout and Chaminade graph the accumulation of technical variation in the making of stone tools over time. The timescale runs from right to left in millions of years.

that marked the Holocene period. Since then, he and I have collaborated on exploring how cultural niche construction theory can begin to help us understand the ENT (Sterelny, Watkins 2015).

On the basis of collaborative research, ethnographic fieldwork and laboratory experiments, Joe Henrich argues similarly for the power of the cultural learning niche for the safe inter-generational transfer of complex knowledge and diverse skills (Henrich 2015). He introduces his book, written after twenty years of research, as a waymark of his current understanding of the story of human evolution. He summarises the central argument of his book as "about 2 million years ago, we crossed this evolutionary Rubicon, at which point cultural evolution became the primary driver of our species genetic evolution. This interaction between cultural and genetic evolution generated a process that can be described as autocatalytic, meaning that it produces the fuel that propels it" (Henrich 2015.57). He shows that the cultural accumulation of innovations is dependent on the existence of very cohesive social groups and a cultural niche that provides for the tutoring, acquisition and practice of complex skills. There is a demographic component in this advanced cultural learning niche: there must be relatively large numbers of people if there are to be several wise and experienced practitioners of complex skills, such as, for example, building a kayak, making a harpoon, and engaging in hunting seals in the Arctic Ocean. The Upper Palaeolithic societies, made up of small, scattered, forager bands that were the constituents of larger scale societies, were remarkably successful; Clive Gamble refers to their ability to network, and to belong to a wider community as the 'release from proximity' (Gamble 1998; 1999). But they were at the limits of their cultural capacity to sustain sufficiently large numbers of people who could maintain meaningful contact with one another.

Kevin Laland is Professor of Behavioral and Evolutionary Biology, and, like Henrich, has recently published a book that summarises decades of collaborative research, describing many years of observation and simulation experiments that illustrate the importance in human evolution of skills in cultural innovation and the capacity for cumulative culture within the cultural niche (Laland 2017). Like Henrich, Laland highlights "the significance of accelerating cycles of evolutionary feedback, whereby an interwoven complex of cultural processes to reinforce each other in an irresistible runaway dynamic that engineered the mind's breathtaking computational power" (Laland 2017. 3). He has worked with archaeologist Mike 0'Brien, and together they have written on the beginnings of agriculture as a case-study in the context of cultural niche construction theory and gene-culture co-evolution, but in neither paper were they considering specifically the example of our ENT (Laland, O'Brien 2010.315-318; O'Brien, Laland 2012). Laland (2017. 240-241) appreciates that "hunter-gatherers are effectively trapped in a vicious cycle that severely constrains their rate of cultural evolution"; hence the significance of developments that he notes, and which can be documented in the Epipalaeolithic of Southwest Asia, such as reduced mobility, the storage of food resources, and reduced birth spacing for accelerating population growth as well as increasing the opportunities for refining and expanding the toolkit. While he discusses in some detail examples of gene-culture evolution among herders and cultivators, such as lactose tolerance and enhanced capacity for digesting starchy cereal-based foodstuffs, he is much less concerned with the social and cognitive demands of living together in large, permanently coresident communities.

\section{Transforming the scale of the human cultural niche}

It should by now be apparent that the evolutionary context within which I wish to set the ENT involves cultural niche construction theory and the idea of 
cumulative culture, in which the authors mentioned in the previous paragraphs are leading figures. After Gordon Childe's 'oasis theory' attributed the beginnings of farming to a supposed desiccation of much of Southwest Asia following the end of the Ice Age, the standard account was established in the 1960s by processualist archaeologists who sought to develop an evolutionary-ecological framework, in which human populations responded to environmental pressures, turning to farming either because of increasing population pressure on finite wild resources, or because of climatic effects (prompted by the discovery of the sudden Younger Dryas phase in the final millennium of the Pleistocene), or because the stability of the warmer, moister, early Holocene climate made agriculture practicable. These are all variants of a view of cultural evolution as adaptations that are responses to environmental pressures. But evolutionary theory has moved on.

By contrast with the mid-twentieth century's socalled modern synthesis or neo-evolutionary theory, recent evolutionary developments are referred to as the forming of an 'extended evolutionary synthesis' in which niche construction plays an important role (Laland et al. 2015). The publication by the evolutionary biologist Richard Dawkins of his notion of the extended phenotype signified the beginning of a major development of evolutionary theory (Dawkins 1978; 1982). As examples of the extended phenotype, Dawkins cited the capacity of animals to modify their environment, such as the protective house formed by the caddis, or the behaviour of beavers in building dams and lodges. He also discussed how organisms of one species may manipulate organisms of another species, such as the manipulation by the cuckoo chick of the host birds that feed it. At very much the same time, several scientists began to use the term co-evolution, and in particular gene-culture coevolution (e.g., Lumsden, Wilson 1981; Durham 1991), or 'dual inheritance theory' (Cavalli-Sforza, Feldman 1981; Boyd, Richerson 1985). The most frequently cited example of human gene-culture coevolution is lactase persistence among some human farming and pastoralist groups that depend on milk in their diet (e.g., Gerbault et al. 2011).

The extended evolutionary synthesis mentioned above refers to these various ideas concerning the extended phenotype and gene-culture coevolution, but the group of leading thinkers who authored that article (Laland et al. 2015) are agreed that niche construction theory is the most significant advance. Niche construction places emphasis on the changes that organisms bring about in their own selective environments (Laland et al. 2001; Odling-Smee et al. 2003). Niche construction is defined as "the process whereby organisms, through their metabolism, their activities and their choices, modify their own and/or each other's niches" (Odling-Smee et al. 2003.419; see also Laland, Sterelny 2006). Many species of animals manufacture nests or burrows, spiders build webs, and so on: humans modify their environments by cultural means in ways that mean that the niche becomes the effective evolutionary environment in which their descendants grow up and learn how to live, and to which they are genetically adapted.

Humans have throughout the evolution of the genus Homo employed cultural means to modify the human niche in many ways, whether through the control of fire, through cooking their food, or making clothing that has enabled them to live in climatically harsh environment. Granted that niche construction theory grew up among biological scientists, it is not surprising that the aspect of cultural niche construction that has received much attention is the role of the domestication of plants and animals and the effects of that culturally modified niche on the domesticates themselves, as well as the reciprocal influences on humans, such as the transfer of diseases from domesticated animals to humans, or changes in the digestive system in response to changes in diet (Perry et al. 2007; Smith 2016; Zeder 2012; 2016; Zeder et al. 2006). But, as Henrich (2015), Laland (2017), Sterelny (2011) and others make clear, the human cultural niche is also constructed to facilitate social learning, the transmission of cultural knowledge and skills, and the apparently unique human capacity for cumulative culture. Michael Tomasello (1999.80) has remarked the capacity of human cultures to accumulate changes over generations, resulting in complex, culturally transmitted knowledge and behaviours that no single human individual could invent on their own. Henrich $(2004 ; 2015)$ argues persuasively that the capacity to sustain a cultural package across generations, to learn information and techniques from others, and to refine and grow the cultural package over generations (cumulative cultural evolution) began at the beginning of the genus Homo. While cultural accumulation may have been almost imperceptibly slow for much of human evolution, it has become more and more rapid, making human minds and lives radically different from those of other animals (Heyes 2012; 2018). 
The interplay between population numbers, social organisation, physical resources and cultural package are characteristics of human cultural niche construction. For humans, cultural niche construction creates not only an ecological but also a cultural inheritance. I think that it is helpful to see the Epipalaeolithic-Neolithic transformation as a dramatic quickening of the transformation of population numbers, social organisation and cultural package that make up the human cultural niche. Compared to the graphs produced by Dunbar and by Stout and Chaminade (Figs. 1 and 2), we are now concentrating our attention on the acceleration of evolutionary change within the relatively recent history of Homo sapiens. These changes took place over such a short time-scale, and, in the context of hominin evolution, so recently, that no significant evolution within the human brain has played a part. Rather, we are in the realm of rapid cultural innovation and accumulation at work in the context of social evolution. The changes in society, in culture, and in the economic basis of society that characterise the EpipalaeolithicNeolithic, by contrast with the preceding millennia of the Palaeolithic period, represent a rapid transformation away from the world of Palaeolithic mobile foraging into a new world. I would characterise what emerged as: the first large-scale societies, formed on the back of a demographic explosion, and supported by labour-intensive, delayed return subsistence strategies that over time developed into efficient farming economies, accompanied and facilitated by the extensive diversification and expansion of complex material and non-material culture. These in- terlinked developments led to further, equally dramatic developments: in particular, the rapid colonisation of new territories within Southwest Asia and far beyond, the rapid diversification of cultural adaptations and the increasingly rapid rate of further social, cultural and economic innovations, so that, only two or three millennia after the Neolithic, we can observe the emergence of urban societies, at the centres of hierarchically organised landscapes, writing and accounting systems, kings, armies, merchants etc.

We can get a proxy handle on population by means of occupation sites and settlements. Anna Belfer-Cohen and Nigel Goring-Morris (2011.Tab. 1) brought together the data on the number of sites in different parts of southwest Asia between the beginning of the Upper Palaeolithic (around 50000 years ago) and the late Neolithic (around 8000 years ago) (Fig. $3)$. While they have collected data for different regions within Southwest Asia, the best data come from the southern Levant, where there has been most work over at least a century. To take account of the different durations of the cultural periods, numbers of sites were normalised relative to the duration of each period. Their graph shows an apparently steady increase, period by period, in the number of sites for the south Levant. If one changes the bar-chart to a graph in which the x-axis is scaled to the shorter and shorter archaeological sub-periods of the Epipalaeolithic and Neolithic, their straight line becomes an accelerating upward curve in the number of sites, implying a crescendo of increasingly dense population.

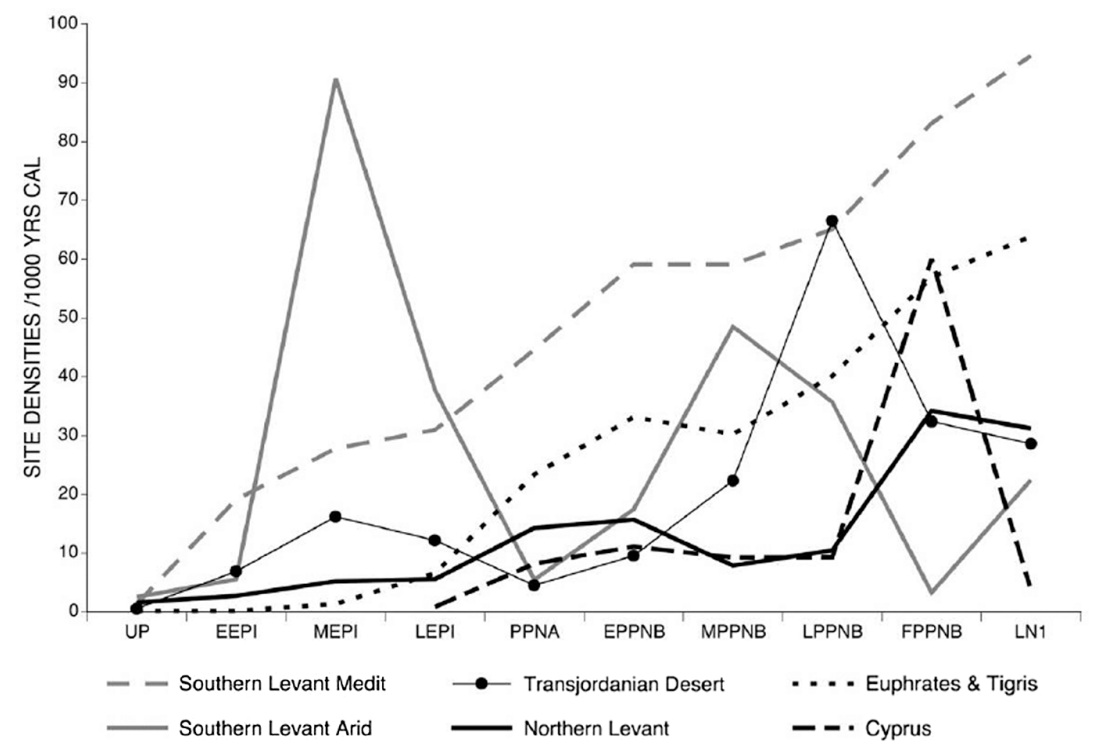

Fig. 3. Goring-Morris and Belfer-Cohen assembled data on the number of occupation and settlement sites from different regions within southwest Asia. The data from the Mediterranean woodland zone of the southern Levant shows a steady increase in settlements period by period.
This curve underplays actual population growth, because over the ENT, sites became larger, were occupied more permanently, and were more intensively built up with increasingly complex buildings. From the data he collected on the size of Neolithic settlement sites in the southern Levant, Ian Kuijt (2000) showed that the number and the average size of settlements increased across the sub-periods of the pre-pottery Neolithic; the largest settlements for each period increased in size exponentially. He also showed that the density of buildings on settlement sites chang- 
ed dramatically through the aceramic Neolithic At the end of the Epipalaeolithic period, roofed structures were scattered, and there was more open space than roofed space; in the final sub-phase of the Pre-Pottery Neolithic, there was limited open space between buildings, and settlements consisted of approx. 75-85\% roofed space. Without attempting to assess how many buildings were domestic residences, or estimating the size of social unit occupying each house, it is clear that over the Epipalaeolithic and Pre-Pottery Neolithic, there was a massive acceleration in the growth of population, with larger and larger numbers of people living together in increasingly densely built-up settlements in an increasingly densely inhabited landscape. Related to this process of increasing numbers of people living together in larger settlements, there were progressive developments in the intensification of subsistence strategies. The rate of cultural innovation and change increased through the 10000 years of the Epipalaeolithic period (the late Epipalaeolithic Natufian is more diverse and elaborated than early Epipalaeolithic cultural packages), but increased much faster through the shorter 4000 years of the Neolithic (notably in the elaboration of symbolic material culture and practices).

\section{The costs and benefits of cumulative culture in the ENT}

The benefits of expanding social group size, living in stable, permanent settlements, and increasing and intensifying the networking of sharing and exchange were the potential of a richer, more diverse cultural package, greater capacity for innovation, stability and resilience. The costs were considerable: the demand for various forms of additional labour (tending crops, management of domestic animals, the creation and maintenance of public buildings, terracing of the settlement site); the additional risks (risks of disease, risks through dependence on a progressively narrower spectrum of resources, crop failure, animal disease); the demands of cooperation and trust within a large community where any individual knows personally only a small proportion of their fellow-citizens, and the need to submit to costly rules and norms of behaviour.

\section{No of sites/millennium}

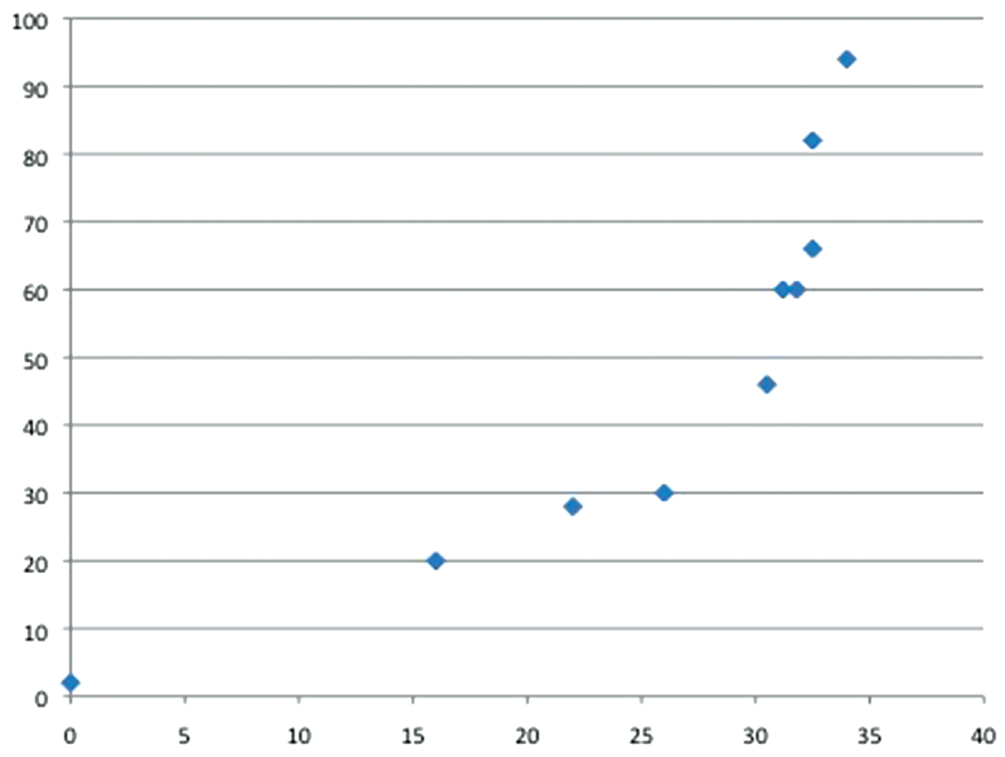

Fig. 4. Using the data for occupation and settlement sties in the Mediterranean woodland zone from Goring-Morris and Belfer-Cohen (2011), the graph plots the numbers against the time-scale of shorter and shorter archaeological periods, starting from the Upper PaAn essential component in the expansion of social group size was the expansion and intensification of networks of sharing and exchange in which the new, large, permanent communities invested (Watkins 2008; in press). Windows on the working of the extensive regional and supra-regional networks are offered through the medium of a variety of goods and materials, but the classic case is the distribution of central and east Anatolian obsidian. We have had the general outline of the distribution of obsidian since the 1960s (Renfrew, Dixon 1968; 1976; Renfrew et al. 1966), but now we know a good deal more, and it is very interesting. We know that the connections that made up this extensive network were already in existence in the Epipalaeolithic period (e.g., Richter et al. 2011), and the steady crescendo in the amount of obsidian and the range of other materials in the network can be charted. But recent work by a Spanish group takes us much further (Ibañez et al. 2015; Ortega et al. 2014). Orte$\mathrm{ga}$, Ibañez and colleagues have simulated exchange networks, and shown that simple 'down-the-line' trading of obsidian based on the assumption that each group kept some of the obsidian that they received, and exchanged some with partners down the line does not work; 'down-the-line' exchange through a network of settlements that extended more than $800 \mathrm{~km}$ from the sources would require that each group kept only a tiny amount, exchanging onwards almost all of the obsidian received (Ortega et al. 
2016.14). Instead, they found that a 'small-world network', in which some participants accessed 'distant links', exchanging with partners up to $120 \mathrm{~km}$ from home in the early Pre-Pottery Neolithic and up to $180 \mathrm{~km}$ in the later Pre-Pottery Neolithic, worked much better. The best fit to the archaeological distribution map for the later pre-Pottery Neolithic is a form of 'optimised distant link' networking, in which certain communities emerge as significant distribution centres specifically for obsidian, and these distribution centres obtain their obsidian directly from other centres that were nearer the Anatolian sources. The researchers also observe that the largest amounts of obsidian relative to flint in the later Pre-Pottery Neolithic occur at the largest settlements in the southern Levant (Ortega et al. 2016.12-13, especially Table 3).

What Ortega and his colleagues are pointing to is something that has been known since the middle of the twentieth century, but, so far as I am aware, has not been the subject of serious study. They have produced diagrams that illustrate the emergence in the Levant in the later Pre-Pottery Neolithic of a sophisticated network in which there are distribution centres that correspond to a map of known settlements in which the relative size of settlements is indicated. By the later Pre-Pottery Neolithic, there was a wide spectrum of settlement site size. The Spanish group is proposing that there were increasingly complex and hierarchical systems of supra-regional interaction and exchange of symbolically important materials, genes (through exchange of marriage partners), and the pooling of ideas, innovations and experience. If it were not dated to the later Pre-Pottery Neolithic, the hierarchy of settlements by size and by importance as distribution centres could be mistaken for a map of a Bronze Age urban settlement and economy.

Something else was new in the Neolithic, emerging out of Epipalaeolithic prototypes: monumental community architecture. The way of life in new, large, permanently co-resident communities that developed through the late Epipalaeolithic and began to flourish in the early Pre-Pottery Neolithic required stronger and materialised modes of cooperation and sharing. Because of its recent publication, Jerf el Ahmar offers the best example (Stordeur 2015; Stordeur et al. 2000). This small settlement site beside the Euphrates in north Syria was never occupied after the early Pre-Pottery Neolithic. Danielle Stordeur was therefore able to expose most of the settlement over the several centuries of its existence. In an early phase of its life, there was a massive subterranean construction at the centre of the cluster of buildings. It was $7 \mathrm{~m}$ in diameter and dug $2 \mathrm{~m}$ deep into the ground. At the end of its life, after being reconstructed or remodelled at least twice, the wooden roof support posts were pulled out, and the roof timbers were set on fire, causing them to collapse onto the floor of the cell-like chambers, where the remains of wheat, barley and lentils were carbonised. We may infer that the cells had served as a storage facility for the community. Around the communal storage building were several communal kitchen buildings equipped with multiple grinding stones. The houses of the community were smaller, simpler buildings that clustered around a central communal area. Although the community was larger than a typical mobile forager band, and although they were engaged in the cultivation of crops, the community seems to have continued the sharing ethic of hunter-gatherer societies. Indeed, their communal food storage was monumentalised in this massive central building. What happened in the open area, with its carefully arranged beaten earth platforms, we do not know. But, as part of the symbolic rituals that accompanied the 'death' of the building, and before the remains of the structure were set on fire, a detached human head was placed in a socket vacated by a roof support post, and the decapitated body of a young woman was thrown onto the floor from the trapdoor in the roof that was the main access to the building. This massive subterranean building was one of a series of similar structures at Jerf el Ahmar, but the later versions were simpler in internal plan; there was a large, circular floor, and a stone-built 'bench' around the foot of the wall. Like the building just described, it seems that each building in the series was deliberately and carefully deconstructed and obliterated at the end of its life.

Jerf el Ahmar was not unique. Similar large, circular, subterranean buildings were found at the nearby contemporary settlement of Tell 'Abr 3 (Yartah 2016), and a massive mud-brick built circular, subterranean structure with three internal buttresses was partly excavated at a third early Pre-Pottery Neolithic settlement in the Euphrates valley at Dja'de; the mud plaster on the inner faces of the wall and buttresses were decorated with panels consisting of intricate geometric designs executed in red, black and white paint (Coqueugniot 2014). Across the upper parts of both the Euphrates (Çayönü) and the Tigris basins (Hallan Çemi, Hasankeyf Höyük, Gusir Höyük) early Pre-Pottery Neolithic settlements also had communal buildings, some of them on a monu- 
mental scale (Atakuman 2014; Kornienko 2009). In the southern Levant, the site of WF16 in southern Jordan had a very large, circular, semi-subterranean structure of complex design, around which were small circular buildings that have been interpreted as communal storage facilities for cereals and/or pulses (Finlayson et al. 2011a; 2011b; Mithen et al. 2011).

The most dramatic example of monumental architecture and sculpture is the site of Göbekli Tepe, on a bare limestone mountain ridge near the city of Urfa in southeast Turkey (Schmidt 2010; 2011). The now famous large, circular, subterranean enclosures of the earlier phase at the site date to the early Pre-Pottery Neolithic, contemporary with settlements like Jerf el Ahmar that have similarly monumental communal buildings. Göbekli Tepe seems to have functioned as a 'central place' - the excavator, the late Klaus Schmidt, compared it to the neutral ceremonial meeting place of an ancient Greek amphictyony. This was the socio-cultural 'central place', where people from many communities in the region demonstrated the reality of their super-community. A series of huge, circular enclosures - up to $30 \mathrm{~m}$ in diameter - are embedded into the main mound, and each is populated by a pair of centrally placed T-shaped monoliths and ten or twelve somewhat smaller monoliths around the perimeter wall. Some of the T-shaped monoliths are explicitly anthropomorphic. The central pair of monoliths in Enclosure D, the tallest monoliths so far discovered at $5.5 \mathrm{~m}$ tall, have human arms and hands. In common with several other monoliths, this pair wear a collar with a pendant at the throat. Each also wears a decorated belt with an elaborate buckle, from which hangs the skin of a fox. Like all the other T-monoliths, the head is a completely faceless, rectilinear block.

Many of the T-monoliths have wild animals (mostly dangerous species and males), large birds, or reptiles, insects, scorpions or spiders carved in raised relief. There are also many other, smaller stone sculptures, many of them consisting of schematised human heads. Many questions about this unique site are still to be resolved, although the dating to the early Pre-Pottery Neolithic and the beginning of the later Pre-Pottery Neolithic is now clear (Dietrich et al. 2013, but many more radiocarbon dates are close to publication). We also now know that there are indications of large-scale feasting (for what must have been a large-scale work-force) on the meat of wild cattle and gazelle, accompanied by beer, and rituals that involved the treatment of the dead (Diet- rich et al. 2012; 2017; Notroff et al. 2015; Pöllath et al. 2017).

There are sculpted T-shape monoliths at a number of sites around Göbekli Tepe in southeast Turkey, but most sites remain unexcavated or undated. The somewhat later settlement site of Nevalı Çori, to the northwest of Göbekli Tepe, possessed a rectangular, semi-subterranean structure that was originally populated by a pair of T-shaped sculpted monoliths in the centre of its stone-paved floor, surrounded by a series of smaller monoliths set into a stone bench around the walls (Hauptmann 1993; 2011). The building is quite unlike the houses of the settlement, and it seems to be a communal building. Nevalı Cori and its communal building is dated to the early part of the later Pre-Pottery Neolithic. Similar rectangular semi-subterranean buildings with a pair of T-shaped monoliths have been found at Göbekli Tepe, where they post-date the massive circular enclosures of the earlier Pre-Pottery Neolithic.

Subterranean or semi-subterranean communal buildings on a monumental scale, T-shaped monoliths, and some of the motifs that are sculpted on the Göbekli Tepe monoliths have been found at other sites in northernmost Syria and southeast Turkey. But there is another class of object that has now been recognised at several settlements in the region. The first to be published were found at Jerf el Ahmar; they are small stone plaques, flat on both surfaces, of a size that would fit easily in the palm of the hand. In one way they are like a class of stones, that are flat on one surface, with a groove running the length of the longer axis. Some of these grooved stones are decorated on the upper surface; they are characteristic of the end of the Epi-palaeolithic and the beginning of the Pre-Pottery Neolithic. But the plaques are different. They have motifs incised on both faces. Some of these motifs are repeated on plaques from different sites, and some of the motifs, like the wriggling snake with the triangular head, are frequently seen on monoliths at Göbekli Tepe. We now have examples of these small stone plaques from a number of early Pre-Pottery Neolithic settlement sites in north Syria and southeast Turkey. It seems that the motifs are signs that are elements in a 'semasiographic' (or ideographic) sign system.

Scripts in pre-Columban Mesoamerica and the Andes were semasiographic (as opposed to glottographic); the proto-cuneiform accounting tablets of late fourth millennium BC southern Mesopotamia, referring to quantities and commodities, were similarly semasio- 
graphic. The philosopher and historian of science Peter Damerow, who had worked with Hans Nissen and Robert Englund on the proto-cuneiform tablets (Nissen et al. 1990; 1993), analysed how such semasiographic systems can function effectively for a community that shares the 'cognitive frame' within which the signs function: "A body of knowledge shared between the partners in a communication process provides cognitive frames that are triggered by the communication process, instantiated by the given incomplete information, and finally complemented by default assumptions about the subject which are retrieved from memory as an effect of the assimilation of this subject to the frame" (Damerow 1999.3). I believe that we can say that there were regional networks of communities in the early Pre-Pottery Neolithic whose shared 'cognitive frames' made their groups of carved signs meaningful, just as groups of mathematicians or theoretical physicists share the 'cognitive frame' that enables them to have a meaningful discussion around a blackboard covered in signs and symbols.

\section{The cognitive-cultural niche and the shared community identity}

I seek to argue that these related modes of material symbolism constituted a significant development of the cultural-cognitive niche, because they facilitated the storing and sharing of ideas and knowledge, directing and constraining the cognition of those who belonged to the community that shared them. While the ability to create meaningful images was, of course, not new, the complex structuring of images, sculptures, and architectural settings, and the emerging evidence of how the elements were created, moved, and reshaped, plus the evidence of the formalised activities at the site represent a major development in the formation of highly affective cognitive niches.

What we see, at least from the beginning of the early Pre-Pottery Neolithic, is a new capacity to form and sustain permanent communities, both at the level of the individual settlement, and at higher levels as regional and even supra-regional communities. The formation of this new kind of symbolic cultural niche involved developments in cognition: the cultural niche interacted with cognition. The idea of a cognitive niche is not new and is certainly not my invention. Two distinguished philosopher-psychologists have written about the cognitive niche. In both cases, they were excited by the way that language materialises thought in words, creating structures that are themselves proper objects of perception, manipulation, and (further) thought. Andy Clark, a leading philosopher interested in the philosophy of mind, talks of language as a kind of self-constructed cognitive niche (Clark 2006.370). He argues that words materialise thoughts that "create structures that are themselves proper objects of perception, manipulation, and (further) thought." The eminent psychologist Steven Pinker, who has worked on language, cognition and mind, similarly talks of the cognitive niche (Pinker 2010). He argues that the distinctive feature of the cultural niche of Homo sapiens is the way that human intelligence, sociality, and language have co-evolved. Here we are not concerned with human language per se; I refer to these distinguished scholars for their views on the co-evolution of human cognition within the human cultural niche, in support of the way that I wish to unfold the accelerating cumulative cultural evolutionary process through the ENT (Watkins 2016). I want to emphasise that there was not only a complex geneculture co-evolutionary process within the human cultural niche (through the cultivation and domestication of plants and herding of animals, with reciprocal effects on the biology of human populations), but also a cultural-cognitive evolutionary development.

Clark and Pinker do not differentiate between spoken and written language, as Merlin Donald emphatically does (Donald 1991; 1993; 2001). Donald labels as 'theoretic culture' the third stage in his account of the evolution of human culture and cognition. Although he was thinking primarily - as a good academic should - in terms of written texts as the prime form of 'external symbolic storage', a medium for the storage and transmission of all kinds of knowledge, he discusses the capacity of art and architecture to serve as shared external symbolic storage, and sees the beginning of the emergence of external symbolic storage systems in Upper Palaeolithic art. In describing the power of systems of 'external symbolic storage', Donald, who began as a neuro-scientist before concentrating on psychology, remarks that the overwhelming influence of symbolic culture in its various forms deeply affects the continual development of our brains and minds to such an extent that cultural changes can actually remodel the operational structure of the cognitive system. What Donald says refers to the capacity of humans to make something like a Byzantine period church, full of mosaics and frescoes, that frames the movements, gestures, words, and the very feeling and thinking of those involved in the liturgy. It is a co-evolutionary feedback loop between symbolic 
material culture - whether carved and built in stone, or inscribed on clay tablets - and the cognitive capacities of those who are members of that community.

\section{Conclusion}

Over a few thousand years - a very brief period on the evolutionary timescale - mobile foraging groups living in rich and favourable environments found ways to create larger and more cohesive communities, transcending by cultural means the biological limits of their inherited brains. We can chart the increasing population density, see something of the increasing size of the co-resident social group, and recognise the increasing scale, intensity and culturalcognitive modes of their networked super-communities. But what we know of the mechanisms that sustained human social networks is still rudimentary; we can see the expansion of Upper Palaeolithic networks of exchange, and recent fieldwork is showing us sites that were occupied seasonally, where people built permanent structures. From the early Epipalaeolithic, there was a new kind of occupation site in the form of huge aggregation sites, where large numbers of people with somewhat different cultural traditions gathered for seemingly lengthy stays (Jones et al. 2016; Maher 2017; Maher et al. 2012). Networks of inter-personal and inter-group relationships were expanded, but could not be expanded without the further development of the symbolic cultural means to sustain large-scale communities. Around the end of the Epipalaeolithic and through the early Pre-Pottery Neolithic, permanent, sedentary communities began to operate within sophisticated networks that constituted super-communities, sharing prized materials, technical know-how, cultural innovations, styles, tastes, and acknowledging that they shared stories and beliefs about the world expressed in symbols and images. Most significantly, these communities and super-communities were constructed as vertically nested, complex identities, something that we can recognise as being fundamental to our own, contemporary experience of complex, nested identities.

There is a rapidly growing body of literature that puts forward evidence that larger social groups are better able both to sustain a complex cultural heritage, to innovate and incorporate innovations, and to withstand competition. I accept the central thesis of Joe Henrich's (2015.57) recently published book on the human facility for cumulative culture: "cultural evolution became the primary driver of our species' genetic evolution". Henrich argues that the key features of human cultural and social evolution have been to ensure that there are sufficient numbers in the population, with effective interconnectedness: the larger and more complex the body of cultural knowledge, ideas, and behaviours, the greater the scale of population that is required to support it, and the greater the need for intensive sociality and social interaction within that population. Robert Boyd offers the same conclusion: that the facility for cultural accumulation depends on the size and interconnectedness of populations (Boyd 2018.53-58), based on the analysis of ethnographic evidence (e.g., Kline, Boyd 2010) and on laboratory simulations (Derex, Boyd 2015; 2016). Further, the experimental work and simulations of Maxime Derex and Boyd show that large populations made up of partially connected groups work best, which is surely what we see in the regional and supra-regional networks of sharing exchange of the early Neolithic.

In the course of the Epipalaeolithic-Neolithic transformation, small-scale, mobile forager band society, a cultural niche that had been highly successful in its own terms (it had supported a massive expansion of population and the spread of Homo sapiens around the diverse environments of Africa, Eurasia and Sahul), was transformed to become a dynamic new kind of niche, based on the first large-scale, permanently co-resident communities that operated within sophisticated networks that constituted socio-cultural super-communities (what Gordon Childe had termed 'cultural groups', or 'cultures'). Within these regional super-communities, people shared prized materials, technical know-how, cultural innovations, styles, tastes, ideas/stories/beliefs/images/symbols. People were no longer bound by 'horizontal' ties between individuals (family, kin, neighbours, those who shared the same settlement, those they knew or encountered every day), but were also invested in vertically nested, complex identities. From this pivotal moment, the pace and scale of social, economic and cultural evolution increased in an ever steeper curve. 


\section{References}

Atakuman C. 2014. Architectural Discourse and Social Transformation during the Early Neolithic of Southeast Anatolia. Journal of World Prehistory 27(1): 1-42. DOI: 10.1007/s10963-014-9070-4

Boyd R. 2018. A Different Kind of Animal: How Culture Transformed Our Species. Princeton University Press. Princeton.

Boyd R., Richerson P. J. 1985. Culture and the evolutionary process. University of Chicago Press. Chicago.

Cavalli-Sforza L. L., Feldman M. W. 1981. Cultural transmission and evolution: a quantitative approach. Princeton University Press. Princeton.

Clark A. 2006. Language, embodiment, and the cognitive niche. Trends in Cognitive Sciences 10(8): 370-374. DOI: 10.1016/j.tics.2006.06.012

2007. A Farewell to Alms: a brief economic history of the world. Princeton University Press. Princeton.

Coqueugniot E. 2014. Dja'de (Syrie) et les représentations symboliques au IXe millénaire cal. BC. In C. Manen, T. Perrin, and J. Guilaine (eds.), La transition néolithique en Méditerranée. The Neolithic transition in the Mediterranean. Errance. Paris: 91-108.

Damerow P. 1999. The Origins of Writing as a Problem of Historical Epistemology. Max-Planck-Institut für Wissenschaftgeschichte. Berlin.

Dawkins R. 1978. Replicator Selection and the Extended Phenotype. Zeitschrift für Tierpsychologie 47(1): 61-76.

1982. The Extended Phenotype. Oxford University Press. Oxford.

Derex M., Boyd R. 2015. The foundations of the human cultural niche. Nature Communications 6: 8398. D0I: 10. 1038/ncomms 9398

2016. Partial connectivity increases cultural accumulation within groups. Proceedings of the National Academy of Sciences of the USA 113(11): 2982-2987. DOI: $10.1073 /$ pnas. 1518798113

Dietrich 0., Heun M., Notroff J., Schmidt K., and Zarnkow M. 2012. The role of cult and feasting in the emergence of Neolithic communities. New evidence from Göbekli Tepe, south-eastern Turkey. Antiquity 86(333): 674-695. DOI: $10.1017 / \mathrm{S} 0003598 X 00047840$

Dietrich 0., Köksal-Schmidt Ç., Notroff J., and Schmidt K. 2013. Establishing a Radiocarbon Sequence for Göbekli
Tepe: State of Research and New Data. Neo-lithics 1(13): 36-41.

Dietrich O., Notroff J., and Schmidt K. 2017. Feasting, Social Complexity, and the Emergence of the Early Neolithic of Upper Mesopotamia: A View from Göbekli Tepe. In R. J. Chacon, R. G. Mendoza (eds.), Feast, Famine or Fighting? Multiple Pathways to Social Complexity. Springer International Publishing. New York: 91-132. DOI: 10. 1007/978-3-319-48402-0_5

Donald M. 1991. Origins of the modern mind: three stages in the evolution of culture and cognition. Harvard University Press. Cambridge, Mass., London.

1993. Précis of Origins of the modern mind: Three stages in the evolution of culture and cognition. Behavioral and Brain Sciences 16(4): 737-748. DOI: 10.1017/ S0140525X00032647

2001. A mind so rare: the evolution of human consciousnes. New York. Norton.

Dunbar R. I. M. 1997. Grooming, gossip and the evolution of language. Faber. London.

1998. The social brain hypothesis. Evolutionary Anthropology 6(3): 178-190. DOI: 10.1002/(SICI)15206505(1998)6:5<178

Durham W. H. 1991. Coevolution: genes, culture, and human diversity. Stanford University Press. Stanford.

Finlayson B., Kuijt I., Mithen S., and Smith S. 2011a. New evidence from Southern Jordan: rethinking the role of architecture in changing societies at the beginning of the Neolithic process. Paléorient 37(1): 123-135. http:// www.jstor.org/stable/41496926

Finlayson B., Mithen S. J., Najjar M., Smith S., Maričević D., Pankhurst N., and Yeomans L. 2011b. Architecture, sedentism, and social complexity at Pre-Pottery Neolithic A WF16, Southern Jordan. Proceedings of the National Academy of Sciences 108(20): 8183-8188. DOI: 10.1073/ pnas. 1017642108

Gamble C. 1998. Palaeolithic society and the release from proximity: a network approach to intimate relations. World Archaeology 29(3): 426-449. DOI: 10.1080/00438243. 1998.9980389

1999. The palaeolithic societies of Europe. Cambridge University Press. Cambridge.

Gerbault P., Liebert A., Itan Y., Powell A., Currat M., Burger J., Swallow D. M., and Thomas M. G. 2011. Evolution 
of lactase persistence: an example of human niche construction. Philosophical Transactions of the Royal Society B: Biological Sciences 366(1566): 863-877. DOI: $10.1098 /$ rstb.2010.0268

Goring-Morris A. N., Belfer-Cohen A. 2011. Neolithization Processes in the Levant: The Outer Envelope. Current Anthropology 52(S4): S195-S208. DOI: 10.1086/658860

Hauptmann H. 1993. Ein Kultgebaüde in Nevali Çori. In M. Frangipane, H. Hauptmann, M. Liverani, P. Matthiae, and M. Mellink (eds.), Between the Rivers and over the Mountains. Università di Roma La Sapienza. Rome: 37-69.

2011. The Urfa Region. In M. Özdoğan, N. Başgelen, and P. Kuniholm (eds.), The Neolithic in Turkey. New Excavations and New Research. The Euphrates Basin. Arkeoloji ve Sanat Yayinlari. Istanbul: 85-138.

Henrich J. 2004. Demography and cultural evolution: How adaptive cultural processes can produce maladaptive losses - The Tasmanian case. American Antiquity 69(2): 197-214. DOI: $10.2307 / 4128416$

2015. The Secret of Our Success: How Culture Is Driving Human Evolution, Domesticating Our Species, and Making Us Smarter. Princeton University Press. Princeton.

Heyes C. 2012. Grist and mills: on the cultural origins of cultural learning. Philosophical Transactions of the Royal Society B: Biological Sciences 367(1599): 21812191. DOI: $10.1098 /$ rstb.2012.0120

2018. Cognitive gadgets: The cultural evolution of thinkin. Harvard University Press. Cambridge.

Ibañez J. J., Ortega D., Campos D., Khalidi L., and Méndez V. 2015. Testing complex networks of interaction at the onset of the Near Eastern Neolithic using modelling of obsidian exchange. Journal of The Royal Society Interface 12: 20150210. DOI: 10.1098/rsif.2015.0210

Jones M. D., Maher L. A., Macdonald D. A., Ryan C., Rambeau C., Black S., and Richter T. 2016. The environmental setting of Epipalaeolithic aggregation site Kharaneh IV. Quaternary International 396: 95-104. DOI: 10. 1016/j.quaint.2015.08.092

Kline M. A., Boyd R. 2010. Population size predicts technological complexity in Oceania. Proceedings of the Royal Society B-Biological Sciences 277(1693): 25592564. DOI: $10.2307 / 25706489$

Kornienko T. V. 2009. Notes on the cult buildings of Northern Mesopotamia in the Aceramic Neolithic period. Journal of near Eastern Studies 68(2): 81-101. D0I: 10. $1086 / 604671$
Kuijt I. 2000. People and Space in Early Agricultural Villages: exploring daily lives, community size and architecture in the late Pre-Pottery Neolithic. Journal of Anthropological Archaeology 19(1): 75-102. DOI: 10.1006/ja ar.1999.0352

Laland K., M. O'Brien 2010. Niche Construction Theory and Archaeology. Journal of Archaeological Method and Theory 17(4): 303-322. DOI: 10.1007/s10816-010-909 6-6

Laland K. N. 2017. Darwin's Unfinished Symphony: How Culture Made the Human Mind. Princeton University Press. Princeton.

Laland K. N., Odling-Smee J., and Feldman M. W. 2001. Cultural niche construction and human evolution. Journal of Evolutionary Biology 14(1): 22-33. DOI: 10.1046/ j.1420-9101.2001.00262.x

Laland K. N., Uller T., Feldman M. W., Sterelny K., Müller G. B., Moczek A., Jablonka E., and Odling-Smee J. 2015. The extended evolutionary synthesis: its structure, assumptions and predictions. Proceedings of the Royal Society B: Biological Sciences 282(1813): 20151019. DOI: 10. 1098/rspb.2015.1019

Lumsden C. J., Wilson E. O. 1981. Genes, mind, and culture: the coevolutionary process. Harvard University Press. Cambridge.

Maher L. 2017. Late Quaternary Refugia, Aggregations, and Palaeoenvironments in the Azraq Basin, Jordan. In Y. Enzel, 0. Bar-Yosef (eds.), Quaternary of the Levant: Environments, Climate Change, and Humans. Cambridge University Press. Cambridge: 679-690.

Maher L. A., Richter T., and Stock J. T. 2012. The Pre-Natufian Epipaleolithic: Long-term Behavioral Trends in the Levant. Evolutionary Anthropology 21(2): 69-81. D0I: 10.1002/evan. 21307

Mithen S., Finlayson B., Smith S., Jenkins E., Najjar M., and Maričević D. 2011. An 11,600 year-old communal structure from the Neolithic of southern Jordan. Antiquity 85 (328): 350-364. DOI: 10.1017/S0003598X00067806

Mokyr J. 2009. The enlightened economy: An economic history of Britain, 1700-1850. Yale University Press. New Haven.

Nissen H. J., Damerow P., and Englund R. K. 1990. Frühe Schrift und Techniken der Wirtschaftsverwaltung im alten Vorder Orient. Franzbecker. Berlin.

Nissen H. J., Damerow P., and Englund R. K. 1993. Archaic bookkeeping: early writing and techniques of economic administration in the ancient Near East. University of Chicago Press. Chicago. 
Notroff J., Dietrich O., and Schmidt K. 2015. Gathering of the Dead? The Early Neolithic sanctuaries of Göbekli Tepe, Southeastern Turkey. In C. Renfrew, M. Boyd, and I. Morley (eds.), Death Rituals, Social Order and the Archaeology of Immortality in the Ancient World: 'Death Shall Have No Dominion'. Cambridge University Press. Cambridge: $65-81$.

O'Brien M. J., Laland K. N. 2012. Genes, Culture, and Agriculture An Example of Human Niche Construction. Current Anthropology 53(4): 434-470. DOI: 10.1086/666 585

Odling-Smee F. J., Laland K. N., and Feldman M. W. 2003. Niche Construction: the neglected process in evolution. Princeton University Press. Princeton.

Ortega D., Ibañez J., Khalidi L., Méndez V., Campos D., and Teira L. 2014. Towards a Multi-Agent-Based Modelling of Obsidian Exchange in the Neolithic Near East. Journal of Archaeological Method and Theory 21(2): 461-45. D0I: 10.1007/s10816-013-9196-1

2016. Systems of Interaction between the First Sedentary Villages in the Near East Exposed Using AgentBased Modelling of Obsidian Exchange. Systems 4(2): 18. DOI: $10.3390 /$ systems 4020018

Perry G. H., Dominy N. J., Claw K. G., Lee A. S., Fiegler H., Redon R., Werner J., Villanea F. A., Mountain J. L., Misra R., Carter N. P., Lee C., and Stone A. C. 2007. Diet and the evolution of human amylase gene copy number variation. Nature Genetics 39: 1256. DOI: 10.1038/ng2123

Pinker S. 2010. The cognitive niche: Coevolution of intelligence, sociality, and language. Proceedings of the $\mathrm{Na}$ tional Academy of Sciences of the United States of America 107 (Supplement 2): 8993-8999. D0I: 10.1073/pn as.0914630107

Pöllath N., Dietrich O., Notroff J., Clare L., Dietrich L., Köksal-Schmidt C.., Schmidt K., and Peters J. 2017. Almost a chest hit: An aurochs humerus with hunting lesion from Göbekli Tepe, south-eastern Turkey, and its implications. Quaternary International 495: 30-48. DOI: 10.1016/j.qu aint.2017.12.003

Renfrew C., Dixon J. E. 1968. Further analyses of Near Eastern obsidians. Proceedings of the Prehistoric Society 34: 319-331. DOI: 10.1017/S0079497X0001392X

1976. Obsidian in West Asia: a review. In G. Sieveking, I. H. Longworth, and K. E. Wilson (eds.), Problems in Economic and Social Archaeology. Duckworth. London: $137-150$.

Renfrew C., Dixon J. E., and Cann E. R. 1966. Obsidian and early cultural contact in the Near East. Proceedings of the Prehistoric Society 32: 30-72. DOI: 10.1017/S0 079497X0001433X

Richter T., Garrard A. N., Allock S., and Maher L. A. 2011. Interaction before Agriculture: Exchanging Material and Sharing Knowledge in the Final Pleistocene Levant. Cambridge Archaeological Journal 21(1): 95-114. DOI: 10. $1017 /$ s0959774311000060

Schmidt K. 2010. Göbekli Tepe - the Stone Age Sanctuaries. New results of ongoing excavations with a special focus on sculptures and high reliefs. Documenta Praehistorica 37: 239-256. D0I: 10.4312/dp.37.21

2011. Göbekli Tepe: A Neolithic site in southeastern Anatolia. In S. Steadman, G. McMahon (eds.), The $O x$ ford Handbook of Ancient Anatolia (10,000-323 $B C E$ ). Oxford University Press. Oxford: 917-933.

Seabright P. 2004. The company of strangers: a natural history of economic life. Princeton University Press. Princeton.

Smith B. D. 2016. Neo-Darwinism, niche construction theory, and the initial domestication of plants and animals. Evolutionary Ecology 30(2): 307-324. DOI: 10.1007/s10 682-015-9797-0

Sterelny K. 2011. The Evolved Apprentice: How Evolution Made Humans Unique. MIT Press. Cambridge.

Sterelny K., Watkins T. 2015. Neolithization in southwest Asia in a context of niche construction theory. Cambridge Archaeological Journal 25(3): 673-691. DOI: 10.1017/ S0959774314000675

Stordeur D. 2015. Le village de Jerf el Ahmar (Syrie, 9500-8700 av. J.-C.): L'architecture, miroir d'une société néolithique complexe. Centre national de la recherche scientifique Éditions. Paris.

Stordeur D., Brenet M., Der Aprahamian G., and Roux J.C. 2000. Les bâtiments communautaires de Jerf el Ahmar et Mureybet, horizon PPNA (Syrie). Paléorient 26(1): 2944.

Stout D., Chaminade T. 2009. Making Tools and Making Sense: Complex, Intentional Behaviour in Human Evolution. Cambridge Archaeological Journal 19(01): 85-96. DOI: $10.1017 / \mathrm{S} 0959774309000055$

2012. Stone tools, language and the brain in human evolution. Philosophical Transactions of the Royal Society B: Biological Sciences 367(1585): 75-87. DOI: $10.1098 /$ rstb.2011.0099

Tomasello M. 1999. The cultural origins of human cognition. Harvard University Press. Cambridge, London. 
Watkins T. 2008. Supra-Regional Networks in the Neolithic of Southwest Asia. Journal of World Prehistory 21 (2): 139-171. DOI: 10.1007/s10963-008-9013-Z

2016. The cultural dimension of cognition. Quaternary International 405(Part A): 91-97. D0I: 10.1016/j.qu aint.2015.02.049

in press. Was the Neolithic New? Extensive networks of sharing and exchange from the African MSA to the Neolithic of southwest Asia. In S. Hansen, F. Klimscha, and J. Renn (eds.), Prehistoric Networks in the longue durée: Palaeolithic Innovations enabling the Neolithic Revolution. Edition Topoi. Berlin.

Yartah T. 2016. Typologie de bâtiments communautaires à Tell 'Abr 3 (PPNA) en Syrie du Nord. Neo-lithics 2(16): 29-49.
Zeder M. A. 2012. The Broad Spectrum Revolution at 40: Resource diversity, intensification, and an alternative to optimal foraging explanations. Journal of Anthropological Archaeology 31(3): 241-264. DOI: 10.1016/j.jaa.20 12.03 .003

2016. Domestication as a model system for niche construction theory. Evolutionary Ecology 30(2): 325348. DOI: $10.1007 / \mathrm{s} 10682-015-9801-8$

Zeder M. A., Emshwiller E., Smith B. D., and Bradley D. G. 2006. Documenting domestication: the intersection of genetics and archaeology. Trends in Genetics 22(3): 139155. DOI: $10.1016 /$ j.tig.2006.01.007

\section{back to contents}

